\title{
Nostocyclopeptides as New Inhibitors of 20S Proteasome
}

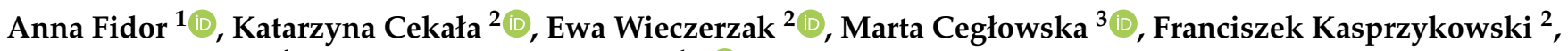 \\ Christine Edwards ${ }^{4}$ and Hanna Mazur-Marzec ${ }^{1, * \mathbb{D}}$ \\ 1 Division of Marine Biotechnology, Institute of Oceanography, University of Gdańsk, \\ Marszałka Józefa Piłsudskiego 46, PL-81378 Gdynia, Poland; anna.fidor@phdstud.ug.edu.pl \\ 2 Department of Biomedical Chemistry, Faculty of Chemistry, University of Gdańsk, Wita Stwosza 63, \\ PL-80308 Gdańsk, Poland; jedrzejewskakatarzyna.92@gmail.com (K.C.); ewa.wieczerzak@ug.edu.pl (E.W.); \\ franciszek.kasprzykowski@ug.edu.pl (F.K.) \\ 3 Institute of Oceanology, Polish Academy of Sciences, Powstańców Warszawy 55, PL-81712 Sopot, Poland; \\ mceglowska@iopan.pl \\ 4 School of Pharmacy and Life Sciences, Robert Gordon University, Aberdeen AB10 7GJ, UK; \\ c.edwards@rgu.ac.uk \\ * Correspondence: hanna.mazur-marzec@ug.edu.pl
}

Citation: Fidor, A.; Cekała, K.; Wieczerzak, E.; Cegłowska, M.; Kasprzykowski, F.; Edwards, C.; Mazur-Marzec, $\mathrm{H}$.

Nostocyclopeptides as New Inhibitors of 205 Proteasome. Biomolecules 2021, 11, 1483. https:// doi.org/10.3390/biom11101483

Academic Editor: Olivier Coux

Received: 1 September 2021

Accepted: 5 October 2021

Published: 8 October 2021

Publisher's Note: MDPI stays neutral with regard to jurisdictional claims in published maps and institutional affiliations.

\begin{abstract}
Nostocyclopeptides (Ncps) are a small class of bioactive nonribosomal peptides produced solely by cyanobacteria of the genus Nostoc. In the current work, six Ncps were isolated from Nostoc edaphicum strain CCNP1411. The bioactivity of these compounds was tested in vitro against 20S proteasome, a proteolytic complex that plays an important role in maintaining cellular proteostasis. Dysfunction of the complex leads to many pathological disorders. The assays indicated selective activity of specific Ncp variants. For two linear peptide aldehydes, Ncp-A2-L and Ncp-E2-L, the inhibitory effects on chymotrypsin-like activity were revealed, while the cyclic variant, Ncp-A2, inactivated the trypsin-like site of this enzymatic complex. The aldehyde group was confirmed to be an important element of the chymotrypsin-like activity inhibitors. The nostocyclopeptides, as novel inhibitors of $20 S$ proteasome, increased the number of natural products that can be considered potential regulators of cellular processes.
\end{abstract}

Keywords: 20 S proteasome inhibitors; cyanobacteria; Nostoc; nostocyclopeptides

\section{Introduction}

The $26 \mathrm{~S}$ proteasome is a large (2.4 MDa), multifunctional and ATP-dependent enzymatic complex with chymotrypsin-like (CT-L), trypsin-like (T-L), and caspase-like (C-L) activities [1-4]. In eukaryotic organisms, it recognizes and degrades proteins with covalently attached ubiquitin (8.5 kDa protein) [5,6]. The $26 \mathrm{~S}$ proteasome is composed of a $20 \mathrm{~S}$ barrel-shaped core particle $(700 \mathrm{kDa})$ responsible for proteolytic activity and one or two $19 \mathrm{~S}$ $(890 \mathrm{kDa})$ regulatory subunits with ubiquitin-binding sites $[3,4,7]$. The $20 \mathrm{~S}$ proteasome also occurs as a free complex that degrades proteins in the ubiquitin-independent pathway $[8,9]$. In humans, the dysfunction of this proteolytic machinery leads to changes in protein profile and, ultimately, to serious health problems. Therefore, proteasome regulators are explored as promising therapeutic agents for a range of diseases (e.g., cancer, autoimmune disorders, inflammation, malaria) [10-12]. The majority of the known $20 S$ proteasome inhibitors belongs to peptide-based structures such as peptide aldehydes, boronates, epoxyketones, or peptide vinyl sulfones [13-15]. Some of the active compounds are of natural origin. Leupeptin, isolated from several strains of Gram-positive bacteria of the order Actinomycetales, inhibits T-L activity of the $20 \mathrm{~S}$ proteasome [16]. Tyropeptin A, a peptide aldehyde produced by the soil Streptomycetales of the genus Kitasatospora, strain MK993-dF2, inhibits mainly CT-L activity [17,18]. Marine fungus Peicillium fellutanum is a producer of fellutamide B, a strong inhibitor of CT-L activity ( $\left.\mathrm{IC}_{50} 9.4 \mathrm{nM}\right)$ with mild effects on T-L $\left(\mathrm{IC}_{50} 2.0 \mu \mathrm{M}\right)$ and $\mathrm{C}-\mathrm{L}\left(\mathrm{IC}_{50} 1.2 \mu \mathrm{M}\right)$ activities [19]. The proteasome inhibition within the nanomolar to the 
micromolar range of $\mathrm{IC}_{50}$ was also documented for metabolites isolated from cyanobacteria Symploca sp., Scytonema hofmannii, and Nostoc.

In our preliminary studies, fractions from Nostoc edaphicum CCNP1411 containing nostocyclopeptides (Ncps) inhibited the chymotrypsin-like activity of the $20 \mathrm{~S}$ proteasome. Ncps constitute a small group of nonribosomal peptides solely produced by cyanobacteria of the genus Nostoc. The biological activity of the peptides was reported in several studies. According to Golakoti et al. [20], Ncp-A1 and Ncp-A2 have cytotoxic activity against human colorectal adenocarcinoma (LoVo) and human nasopharyngeal (KB) cell lines $\left(\mathrm{IC}_{50}\right.$ ca. $\left.1 \mu \mathrm{M}\right)$. Another nostocyclopeptide variant, Ncp-M1, was shown to inhibit the transport of toxic microcystin-LR and nodularin into hepatocytes by blocking organic anion transporter polypeptides, OATP1B1, and OATP1B3. These polypeptides are also overexpressed in cancer cells [21,22]. The role of Ncp-M1 and its analogs as antitumor agents and as tools to study membrane transport was proposed [21,23,24].

Given the pharmaceutical potential of Ncps, the recognition of their action on different cellular targets is important. In the current work, the effects of Ncps on the 20S proteasome were explored. To determine structure-activity relationship, six different Ncps isolated from the Baltic cyanobacterium N. edaphicum CCNP1411 were tested, including linear and cyclic Ncp variants.

\section{Materials and Methods}

\subsection{Organism, Extraction, and Isolation of Compounds}

Nostoc edaphicum strain CCNP1411 (GenBank Accession Number: PRJNA638531) was isolated from the Gulf of Gdańsk, southern Baltic Sea. The cyanobacterium was grown in a $\mathrm{Z} 8$ medium enriched with $\mathrm{NaCl}$ [25]. The culture was kept in $2 \mathrm{~L}$ flasks at $22 \pm 1{ }^{\circ} \mathrm{C}$ and light of 5-10 $\mu \mathrm{mol}$ photons $\mathrm{m}^{-2} \mathrm{~s}^{-1}$. After three weeks, the biomass was harvested using a nylon net (mesh size $25 \mu \mathrm{m}$ ).

The freeze-dried biomass of CCNP1411 (20 g) was homogenized and extracted four times with $75 \%$ methanol $(\mathrm{MeOH})$ in MilliQ water $(4 \times 150 \mathrm{~mL})$ by vortexing for $30 \mathrm{~min}$. The extracts were centrifuged at $12,000 \times g$ for $15 \mathrm{~min}$ at $4{ }^{\circ} \mathrm{C}$. Combined supernatants were diluted with MilliQ water to achieve the final concentration of $\mathrm{MeOH}<10 \%$. Isolation of Ncps was performed using the HPLC system (Shimadzu Corporation, Kyoto, Japan). During all chromatographic runs, the absorbance was monitored at $210 \mathrm{~nm}$ and $270 \mathrm{~nm}$. The diluted sample was loaded onto a preconditioned $120 \mathrm{~g}$ SNAP KP-C18-HS column $(100 \AA, 30 \mu \mathrm{m})$ (Biotage, Uppsala, Sweden). The flash chromatography was performed with a mobile phase consisting of MilliQ water (phase A) and $100 \% \mathrm{MeOH}$ (phase B) using a step gradient from 10 to $100 \%$ B over $180 \mathrm{~min}$ (flow rate $12 \mathrm{~mL} \mathrm{~min}^{-1}$ ). The volume of the fractions collected was $40 \mathrm{~mL}$. Ncps-containing fractions were pooled, concentrated, and separated on Jupiter Proteo C12 column ( $250 \times 21.2 \mathrm{~mm} ; 90 \AA ̊ \AA 4 \mu \mathrm{m})$ (Phenomenex, Torrance, CA, USA). The mobile phase was composed of $5 \% \mathrm{CH}_{3} \mathrm{CN}$ in MilliQ water (phase A) and $100 \% \mathrm{CH}_{3} \mathrm{CN}$ (phase $\mathrm{B}$ ), both containing $0.1 \%$ of formic acid (flow rate $\left.12 \mathrm{~mL} \mathrm{~min}^{-1}\right)$. The chromatographic run (15-100\% B) took $110 \mathrm{~min}$, and $2 \mathrm{~mL}$ fractions were collected. All fractions containing Ncps mixture were combined, concentrated, and subjected to further separation under modified conditions. The gradient started at $15 \%$ B and for the first hour the content of phase B increased by $1 \%$ every $15 \mathrm{~min}$ up to $19 \% \mathrm{~B}$. This concentration was maintained for the next $20 \mathrm{~min}$, and then within $30 \mathrm{~min}$, it increased linearly to $100 \%$ B. Pure Ncps (Ncp-A2 and Ncp-E4-L) were present in fractions eluted in the range $15-25 \%$ of phase $B$.

The remaining fractions containing Ncps were pooled, and the other four individual peptides were isolated using an analytical Agilent HPLC 1200 Series system (Agilent Technologies, Santa Clara, CA, USA) with a diode array detector (DAD) operating at 210 and $270 \mathrm{~nm}$. Ncp-A1 was isolated using Jupiter Proteo C12 column $(250 \times 4.6 \mathrm{~mm}, 90 \AA, 4 \mu \mathrm{m})$ (Phenomenex, Torrance, CA, USA), while Ncp-A2-L, Ncp-E2, and its linear analog Ncp-E2$\mathrm{L}$, were isolated on Zorbax Eclipse XDB-C18 column $(4.6 \times 150 \mathrm{~mm} ; 80 \AA$; $5 \mu \mathrm{m})$ (Agilent Technologies, Santa Clara, CA, USA). During all analytical chromatographic runs, the same 
mobile phase (at flow rate $0.5 \mathrm{~mL} \mathrm{~min}^{-1}$ ) was used as for the preparative separations. Ncps were eluted when the mobile phase contained $16-43 \%$ B. Identification and purity of peptides in individual fractions and subfractions were achieved by LC-MS/MS analysis at each purification step. Analyses were carried out using Agilent 1200 HPLC (Agilent Technologies, Santa Clara, CA, USA) coupled to a QTRAP5500 triple-quadrupole/linear ion trap mass spectrometer (Applied Biosystems MDS Sciex, Concord, ON, Canada), as previously described [26]. Chromatographic separation was performed on a Zorbax Eclipse XDB-C18 column $(4.6 \times 150 \mathrm{~mm} ; 80 \AA ; 5 \mu \mathrm{m})$ using gradient elution with the same mobile phase as for the HPLC-DAD analyses. The mass spectrometer operated under the positive Turbo Ion Spray ionization mode $\left(5.5 \mathrm{kV}, 550{ }^{\circ} \mathrm{C}\right)$. Tandem mass spectra were acquired at collision energy $60 \mathrm{~V}$.

\subsection{NMR Analysis}

The $1 \mathrm{D}{ }^{1} \mathrm{H}$ NMR and 2D homo- and heteronuclear NMR (COSY, TOCSY, ROESY, HSQC, and HMBC) were acquired with the application of Bruker Avance III spectrometers, $500 \mathrm{MHz}$ and $700 \mathrm{MHz}$ (Bruker, Billerica, MA, USA). Spectra were recorded in $\mathrm{H}_{2} \mathrm{O}: \mathrm{D}_{2} \mathrm{O}$ (9:1). NMR data were processed and analyzed by TopSpin (Bruker, Billerica, MA, USA) and SPARKY software (3.114, Goddard and Kneller, freeware https: / / www.cgl.ucsf.edu / home/sparky).

\subsection{Human 20S Inhibition Assay}

The $20 \mathrm{~S}$ proteasome inhibition assay was performed following the procedure of Czerwonka et al. [27]. Human 20S proteasome (h20S) isolated from erythrocytes was used. Latent h20S was activated with $0.01 \%$ SDS (sodium dodecyl sulfate). The final concentration of the proteasome was $1 \mu \mathrm{g} \mathrm{mL} \mathrm{mL}^{-1}(1.4 \mathrm{nM})$. The fluorogenic substrates, SucLLVY-AMC, Boc-LRR-AMC, and Z-LLE-AMC, were used as probes in the chymotrypsinlike, trypsin, and caspase-like activity assays, respectively, at a final concentration of $100 \mu \mathrm{M}$. Stock solutions of Ncps $(10 \mathrm{mM})$ were prepared in dimethyl sulfoxide (DMSO) and were tested in the concentration range of 5 to $50 \mu \mathrm{M}$. The content of DMSO never exceeded $3 \%$ of the final reaction volume. The assays were performed in a 96 -well plate in $50 \mathrm{mM}$ TrisHCl, $\mathrm{pH} 8.0$, at $37^{\circ} \mathrm{C}$. The percentage of the substrate hydrolysis was measured by the amount of the released AMC (aminomethyl coumarin) using Tecan Infinite M200 Pro $(\lambda=380-460 \mathrm{~nm})$ spectrofluorimeter (Tecan Trading AG, Männedorf, Switzerland). The fluorescence measurements were performed at 2-min intervals for $60 \mathrm{~min}$. The activity of h20S in the presence of isolated Ncps was calculated in relation to the control (DMSO). The known proteasome inhibitor PR11 [28] was used to ensure the correctness of the assay. The peptide at the final concentration of $0.2 \mu \mathrm{M}$ decreases the relative CT-L activity of the h20S to $6 \%$ of the control.

\section{Results and Discussion}

Thus far, the presence of Ncps was reported in five strains of Nostoc isolated from different habitats [20,23,29-31]. This includes two Baltic strains: XSPORK 13A producing the cyclic Ncp-M1 [23] and CCNP1411 producing 10 other Ncps variants [31]. The putative structures of the five linear and five cyclic Ncps variants produced by CCNP1411 were elucidated based on mass spectra fragmentation patterns [31]. Two of the cyclic forms, Ncp-A1 and Ncp-A2, enclosed by imino linkage between the $N$-terminal amine group of conserved Tyr and C-terminal aldehyde group of Leu or Phe, were previously identified in Nostoc sp. ATCC53789 isolated from lichen [20]. In position 6 of the Ncps from CCNP1411, 4-methylproline (MePro) or Pro is present, while Ile or Val is in position 4 (Figure 1). In the current study, we were able to isolate 6 out of 10 Ncps produced by CCNP1411 (Table 1): three cyclic variants (Ncp-A1, Ncp-A2, and Ncp-E2), two linear aldehyde forms of the cyclic variants (Ncp-A2-L and Ncp-E2-L), and the six-amino acid peptide Ncp-E4-L lacking the aldehyde group in the C-terminus. In the case of four other Ncps produced by CCNP1411 (Ncp-A1-L, Ncp-E1, Ncp-E1-L, Ncp-E3), their purity and/or quantities were not sufficient 
for inclusion in the study. Ncp-A2-L (Figure 1) was the only variant obtained in sufficient amounts for NMR analyses. The ${ }^{1} \mathrm{H}$ NMR spectrum of Ncp-A2-L displayed a typical pattern of a peptide. The COSY, TOCSY, and HMBC experiments allowed for the identification of the residues in Ncp-A2-L as Tyr, Gly, Gln, Ile, Ser, MePro, and phenylalaninal (Phe-H) (Table 2, Figures 1 and S1-S5). The amino acid sequence was confirmed by TOCSY data. The presence of two aromatic amino acid residues was recognized by the signals occurring in the aromatic region of the spectrum $\left(\delta_{\mathrm{H}} 6.78-7.26 \mathrm{ppm}\right)$. One of them was identified as tyrosine-based on the $\mathrm{AA}^{\prime} \mathrm{BB}^{\prime}$ spin system between the aromatic protons (Tyr-H5/5' and Tyr-H6/6' $, \mathrm{JH}, \mathrm{H}=8.0 \mathrm{~Hz}$ ). The second aromatic residue was identified as phenylalanine based on the TOCSY interaction between 34,35 , and 36 protons and the HMBC correlation from two diastereotopic methylene protons $32 \mathrm{a}\left(\delta_{\mathrm{H}} 2.57 \mathrm{ppm}\right)$ and $32 \mathrm{~b}\left(\delta_{\mathrm{H}} 2.98 \mathrm{ppm}\right)$ to the aromatic $34 / 34^{\prime}$ carbons (Figures S3 and S5). The 4-methyl group of the proline residue was identified based on the ${ }^{1} \mathrm{H}$ NMR doublet signal at $\delta 0.82 \mathrm{ppm}$ (protons 29) and the HMBC correlation between the methyl protons with $26\left(\delta_{C} 37.3 \mathrm{ppm}\right)$ and $28\left(\delta_{C} 55.0 \mathrm{ppm}\right)$ carbons (Figures S1 and S5). The signal at $\delta_{\mathrm{H}} 9.46 \mathrm{ppm}$ was assigned to phenylalaninal aldehyde proton. The occurrence of the studied compound in the linear form was further confirmed by the lack of the ROESY correlation between tyrosine and phenylalanine residues.

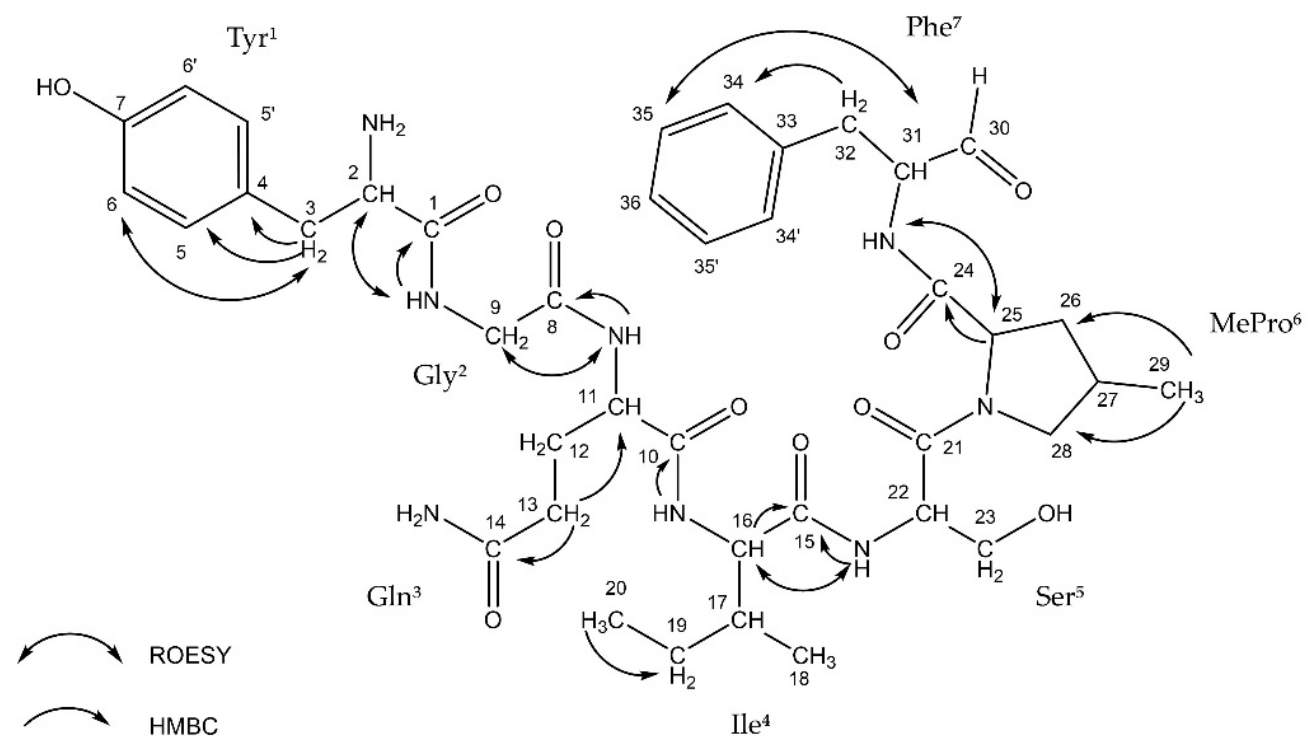

Figure 1. ROESY and HMBC correlations in nostocyclopeptide Ncp-A2-L.

Table 1. Structures of six nostocyclopeptide-variants isolated from Nostoc edaphicum CCNP1411 as pure compounds.

\begin{tabular}{ccc}
\hline Peptide Name & Molecular Mass & Structure \\
\hline Ncp-A1 & 756 & {$\left[\mathrm{Tyr}^{1}+\mathrm{Gly}^{2}+\mathrm{Gln}^{3}+\mathrm{Ile}^{4}+\mathrm{Ser}^{5}+\mathrm{MePro}^{6}+\mathrm{Leu}^{7}\right]$} \\
\hline Ncp-A2 & 790 & {$\left[\mathrm{Tyr}^{1}+\mathrm{Gly}^{2}+\mathrm{Gln}^{3}+\mathrm{Ile}^{4}+\mathrm{Ser}^{5}+\mathrm{MePro}^{6}+\mathrm{Phe}^{7}\right]$} \\
Ncp-A2-L & 808 & $\mathrm{Tyr}^{1}+\mathrm{Gly}^{2}+\mathrm{Gln}^{3}+\mathrm{Ile}^{4}+\mathrm{Ser}^{5}+\mathrm{MePro}^{6}+\mathrm{Phe}^{-\mathrm{H}^{7}}$ \\
\hline Ncp-E2 & 742 & {$\left[\mathrm{Tyr}^{1}+\mathrm{Gly}^{2}+\mathrm{Gln}^{3}+\mathrm{Ile}^{4}+\mathrm{Ser}^{5}+\mathrm{Pro}^{6}+\mathrm{Leu}^{7}\right]$} \\
Ncp-E2-L & 760 & $\mathrm{Tyr}^{1}+\mathrm{Gly}^{2}+\mathrm{Gln}^{3}+\mathrm{Ile}^{4}+\mathrm{Ser}^{5}+\mathrm{Pro}^{6}+\mathrm{Leu}^{7}{ }^{7}$ \\
\hline Ncp-E4-L & 676 & $\mathrm{Tyr}^{1}+\mathrm{Gly}^{2}+\mathrm{Gln}^{3}+\mathrm{Ile}^{4}+\mathrm{Ser}^{5}+\mathrm{MePro}^{6}$ \\
\hline
\end{tabular}


Table 2. Nuclear Magnetic Resonance (NMR) Spectroscopic Data for Ncp-A2-L (Tyr-Gly-Gln-Ile-Ser-MePro-Phe-H).

\begin{tabular}{|c|c|c|c|c|c|}
\hline Residue & Position & $\delta_{C}$, type & $\delta_{\mathrm{H}}(J$ in $\mathrm{Hz})$ & ROESY & НMBC $^{a}$ \\
\hline \multirow{9}{*}{ Tyr } & 1 & & & & \multirow{9}{*}{$2,4,5$} \\
\hline & 2 & $169.9, \mathrm{C}$ & & & \\
\hline & 3 & $54.6, \mathrm{CH}$ & $4.13, \mathrm{t}(6.9,6.9)$ & $\mathrm{NH}(1), 6$ & \\
\hline & 4 & $36.0, \mathrm{CH}_{2}$ & $3.04, \mathrm{dd}(7.3,12.9)$ & 6 & \\
\hline & $5 / 5^{\prime}$ & $125.5, \mathrm{C}$ & & & \\
\hline & $6 / 6^{\prime}$ & $130.9, \mathrm{CH}$ & $6.78, \mathrm{~d}(8.0)$ & & \\
\hline & 7 & $115.9, \mathrm{CH}$ & $7.04, \mathrm{~d}(8.0)$ & 2,3 & \\
\hline & $\mathrm{NH}_{2}$ & 155.3, C & & & \\
\hline & $\mathrm{OH}$ & & & & \\
\hline \multirow{3}{*}{ Gly } & 8 & $170.7, \mathrm{C}$ & & & \multirow[b]{3}{*}{1} \\
\hline & 9 & $42.4, \mathrm{CH}_{2}$ & $3.84, \mathrm{~m}$ & $\mathrm{NH}(2)$ & \\
\hline & $\mathrm{NH}(1)$ & & $8.46, \mathrm{t}(5.6,5.6)$ & 2 & \\
\hline \multirow{8}{*}{ Gln } & 10 & & & & \multirow{5}{*}{10} \\
\hline & 11 & $173.1, \mathrm{C}$ & & $\mathrm{NH}(3)$ & \\
\hline & $12 \mathrm{a}$ & $53.2, \mathrm{CH}$ & $4.30, \mathrm{~m}$ & & \\
\hline & $12 b$ & $27.2, \mathrm{CH}_{2}$ & $1.88, \mathrm{~m}$ & & \\
\hline & 13 & & $1.99, \mathrm{~m}$ & & \\
\hline & 14 & $31.1, \mathrm{CH}_{2}$ & $2.26, \mathrm{t}(7.3,7.3)$ & & $11,12,14$ \\
\hline & $\mathrm{NH}(2)$ & $178.0, \mathrm{C}$ & & 9 & \\
\hline & $\mathrm{NH}_{2}$ & & $8.25, \mathrm{~d}(7.6)$ & & 8 \\
\hline \multirow{7}{*}{ Ile } & 15 & $173.4, \mathrm{C}$ & & \multirow{5}{*}{$\mathrm{NH}(4)$} & \multirow{7}{*}{$\begin{array}{c}17,19 \\
10\end{array}$} \\
\hline & 16 & $58.2, \mathrm{CH}$ & $4.09, \mathrm{t}(8.1,8.1)$ & & \\
\hline & 17 & $36.0, \mathrm{CH}$ & $1.77, \mathrm{~m}$ & & \\
\hline & 18 & $14.7, \mathrm{CH}_{3}$ & $1.08, \mathrm{~d}(6.6)$ & & \\
\hline & 19 & $24.6, \mathrm{CH}_{2}$ & $1.32, \mathrm{~m}$ & & \\
\hline & 20 & $10.0, \mathrm{CH}_{3}$ & $0.79, \mathrm{t}(7.3,7.3)$ & 22 & \\
\hline & $\mathrm{NH}(3)$ & & $8.21, \mathrm{~d}(6.8)$ & 11 & \\
\hline \multirow{6}{*}{ Ser } & 21 & & & \multirow{5}{*}{20} & \\
\hline & 22 & n.o. & & & \\
\hline & $23 a$ & n.o. & $4.59, \mathrm{~m}$ & & \\
\hline & $23 b$ & $61.0, \mathrm{CH}_{2}$ & $3.69, \mathrm{~m}$ & & \\
\hline & $\mathrm{NH}(4)$ & & $3.77, \mathrm{~m}$ & & \\
\hline & $\mathrm{OH}$ & & $8.31, \mathrm{~d}(5.1)$ & 16 & 15 \\
\hline \multirow{7}{*}{ MePro } & 24 & $173.8, \mathrm{C}$ & & \multirow{7}{*}{$\mathrm{NH}(5)$} & \multirow{5}{*}{24} \\
\hline & 25 & $61.3, \mathrm{CH}$ & $4.15, \mathrm{dd}(8.1,9.3)$ & & \\
\hline & 26 & 37.3, $\mathrm{CH}_{2}$ & $2.13, \mathrm{~m}$ & & \\
\hline & 27 & $33.1, \mathrm{CH}$ & $2.04, \mathrm{~m}$ & & \\
\hline & $28 \mathrm{a}$ & $55.0, \mathrm{CH}_{2}$ & $2.84, \mathrm{t}(10.5,10.5)$ & & \\
\hline & $28 b$ & & $3.86, \mathrm{~m}$ & & 26 \\
\hline & 29 & $15.2, \mathrm{CH}_{3}$ & $0.82, \mathrm{~d}(6.6)$ & & 26,28 \\
\hline \multirow{9}{*}{ Phe-H } & 30 & & $9.46, \mathrm{~s}$ & & \multirow{8}{*}{$34 / 34^{\prime}$} \\
\hline & 31 & n.o. & $4.01, \mathrm{~m}$ & 35 & \\
\hline & $32 a$ & $55.5, \mathrm{CH}$ & $2.57, \mathrm{dd}(10.6,14.0)$ & 34 & \\
\hline & $32 b$ & $34.2, \mathrm{CH}_{2}$ & $2.98, \mathrm{dd}(4.0,14.5)$ & & \\
\hline & 33 & & & 32 & \\
\hline & $34 / 34^{\prime}$ & $137.9, \mathrm{C}$ & $7.26, \mathrm{~m}$ & & \\
\hline & $35 / 35^{\prime}$ & $129.5, \mathrm{CH}$ & $7.15, \mathrm{~d}(7.2)$ & 31 & \\
\hline & 36 & $128.7, \mathrm{CH}$ & $7.18, \mathrm{~m}$ & & \\
\hline & $\mathrm{NH}(5)$ & $126.6, \mathrm{CH}$ & $7.46, \mathrm{~d}(9.3)$ & 25 & 24 \\
\hline
\end{tabular}

${ }^{a} \mathrm{HMBC}$ correlations are given from proton(s) stated to the indicated carbon atom.

In our preliminary studies with the application of the human $20 \mathrm{~S}$ proteasome, the Ncpcontaining fractions of CCNP1411 inhibited CT-L activity at micromolar concentrations. In the current work, to unequivocally state which of the cyanobacterial metabolites are responsible for this activity, the six isolated Ncps were assayed. For three cyclic Ncps (Ncp-A1, Ncp-A2, Ncp-E2) and the six-amino acid linear variant without an aldehyde 
group (Ncp-E4-L), no effects on CT-L activity of the human 20S proteasome were observed (Figure 2A). This activity was inhibited only by two linear peptide aldehydes, Ncp-A2$\mathrm{L}$ and Ncp-E2-L, applied at $50 \mu \mathrm{M}$ (Figure 2A). As the two Ncps differ in position 6 (Pro/MePro) and the C-terminal amino acid (Leu/Phe), it can be concluded that these residues do not affect the CT-L activity. Nostocyclopeptide Ncp-E2-L, as well as the widely used synthetic proteasome inhibitor MG-132 [32,33], contain the aldehyde group on Cterminal Leu. The potent activity of MG-132 $\left(\mathrm{IC}_{50} 0.11 \mu \mathrm{M}\right)$ [34] was attributed to the formation of the hemiacetal covalent bond between the aldehyde group of $C$-terminal Leu and the hydroxyl group of Thr1 present in the active site of the proteasome [35]. Another bioactive linear nostocyclopeptide from CCNP1411, Ncp-A2-L, also has the C-terminal amino acid aldehyde (Phe), which again confirms the importance of the aldehyde group for the CT-L inhibition $[14,36]$. Due to the limited amounts of the isolated Ncps, their effects on T-L and C-L activities were examined with no replications. In the assays, only the cyclic Ncp-A2 showed concentration-dependent inhibition of T-L activity (Figure 2B) and had weak effects on C-L activity (Figure 2C). The other Ncp variants had no clear effects on the two proteolytic sites.

The two linear Ncps, Ncp-A2-L and Ncp-E2-L, moderately decreased the CT-L activity $\left(\mathrm{IC}_{50} \mathrm{ca} .50 \mu \mathrm{M}\right)$, compared with several known aldehyde-containing proteasome inhibitors [13]. However, this moderate potency of the Ncps is compensated by their high specificity. Unlike many other peptide aldehydes, which inhibit a wide range of proteases $[13,36]$, the two Ncps interacted with the CT-L site but did not modify the T-L and C-L activities.
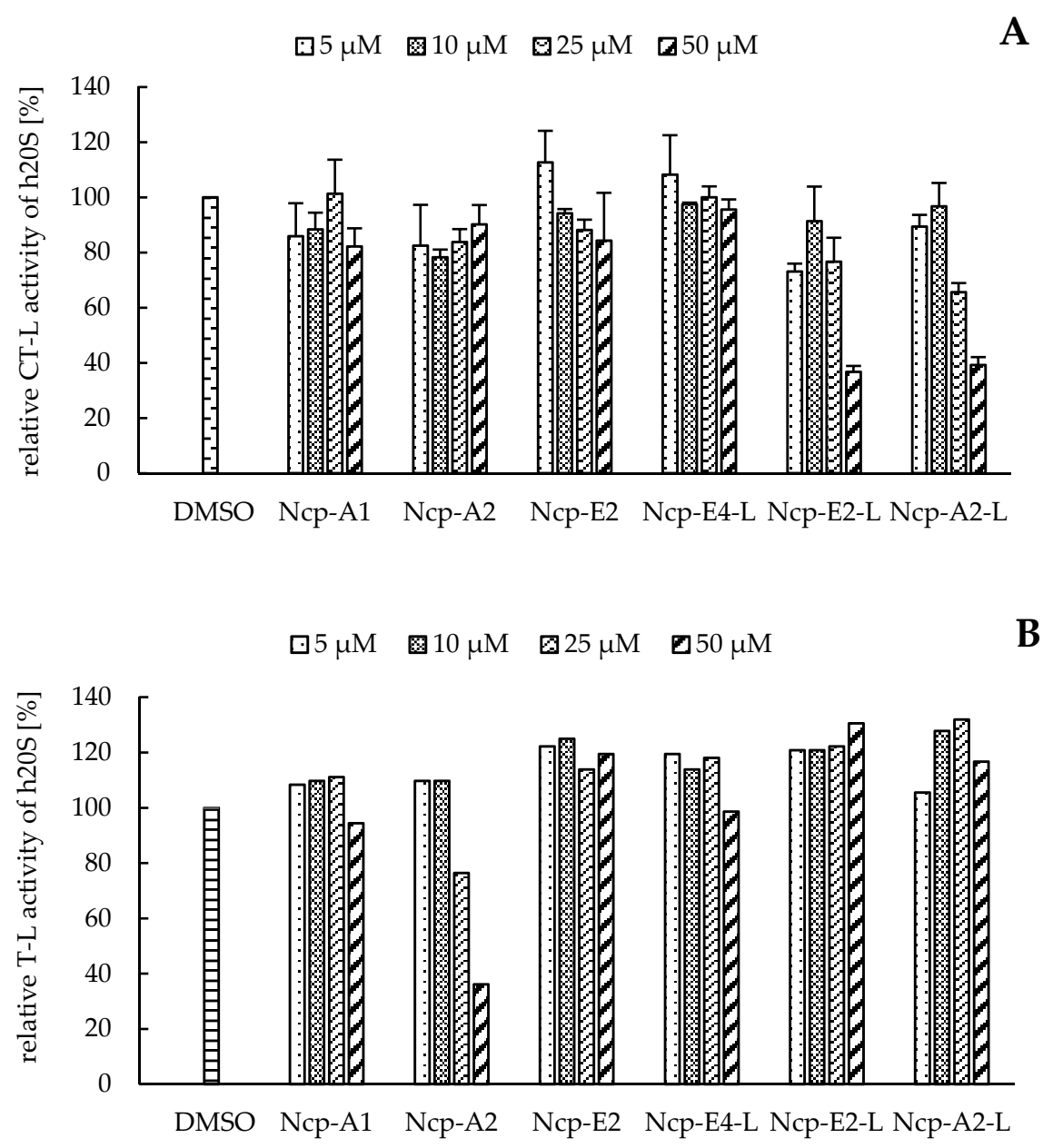

Figure 2. Cont. 


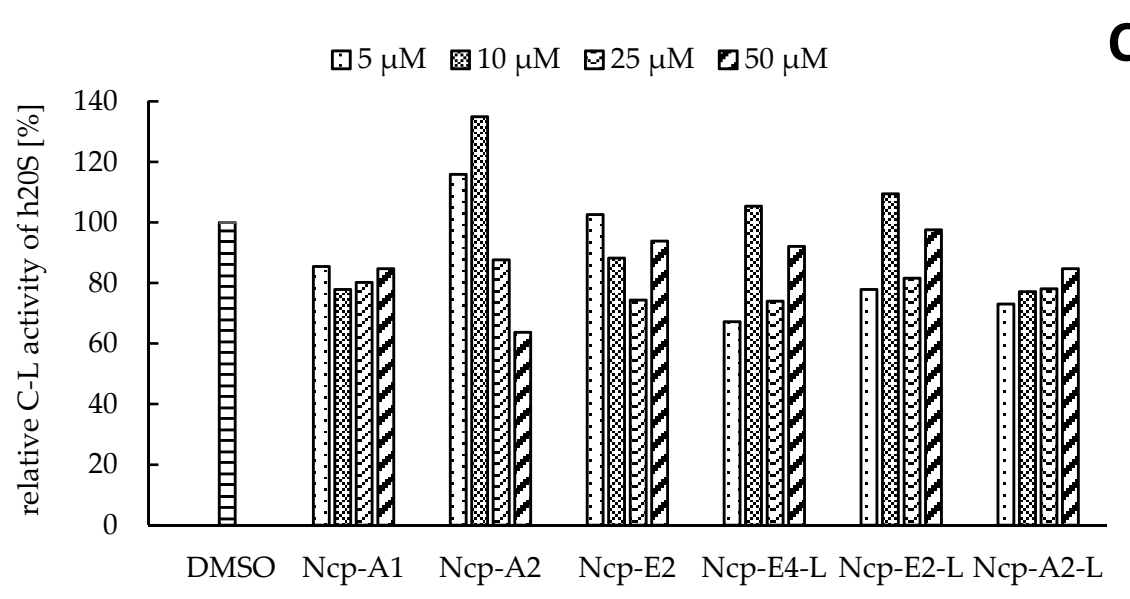

Figure 2. The effects of cyclic and linear (L) nostocyclopeptides (Ncps) on the CT-L (A), T-L (B), and C-L (C) activities of the human 20S proteasome. DMSO was used as a control, and PR11 was used to ensure the correctness of the assay. In the CT-L activity assay, all Ncp variants were tested in triplicate.

Among cyanobacteria metabolites, $\alpha, \beta$-epoxyketones carmaphycin A and $\mathrm{B}$, isolated from Symploca sp., were found to inhibit CT-L activity of the Saccharomyces cerevisiae $20 \mathrm{~S}$ proteasome at low nanomolar concentrations [37]. The authors suggested that the sulfoxide/sulfone moieties in the methionine-derived residues of the inhibitor are crucial for the interaction with the enzyme complex. Nostodione A from Scytonema hofmannii, which inhibits CT-L activity $\left(\mathrm{IC}_{50} 50 \mu \mathrm{M}\right)$, contains indole moiety fused with diketone system [38]. Other cyclic metabolites from cyanobacteria have demonstrated inhibitory effects against $20 \mathrm{~S}$ complex. For example, scytonemide A from $S$. hofmannii, a cyclic peptide characterized by the presence of a unique imino linkage, inhibited catalytic activity of proteasome at $\mathrm{IC}_{50} 96 \mathrm{nM}$ [39]. Krunic et al. [39] suggested that Gln residue contributed to structural conformation in this peptide, enabling optimal binding at the active site. On the other hand the presence of an imine enabled the formation of a covalent bond. Nostoc-derived (Nostoc sp. UIC 10022A) cylindrocyclophanes were active against the $20 \mathrm{~S}$ proteasome in a wide range of activities $\left(\mathrm{IC}_{50} 2.2-100 \mu \mathrm{M}\right)$. According to the authors, dichloromethyl moiety was crucial to achieving a higher level of inhibition [40].

The proteasome is an important drug target in a variety of diseases [10-12]. Currently, three proteasome inhibitors, approved by the American Food and Drug Administration (FDA), are clinically used for the treatment of multiple myeloma (MM) and mantle cell lymphoma (MVL) patients: bortezomib (Velcade) [41], carfilzomib (Kyprolis) [42] and ixazomib (Ninlaro) [43]. Unfortunately, despite the initial promising effects and high efficacy of the proteasome inhibitors in MM treatment, in many patients, resistance has developed. Moreover, some patients do not respond to this treatment, or the side effects of the drugs are too severe [44-47].

Currently, the application of proteasome inhibitors in the treatment of other diseases, e.g., in autoimmune disorders, inflammation, or malaria, is explored $[4,48]$. Further studies are also performed to better understand the effect of specific proteasome inhibitors on general protein homeostasis. In parallel, screening for novel agents with a potential therapeutic application as regulators of the $20 \mathrm{~S}$ proteasome and other components of the ubiquitin-proteasome system is continued [49,50]. Regardless of the low potency, Ncps still can be considered as starting points for drug development. As in the case of many bioactive natural products, their activity and selectivity can be optimized by structural modifications so that the final compound can demonstrate a better therapeutic potential.

\section{Conclusions}

Nostoc edaphicum strain CCNP1411 produces 10 nostocyclopeptides, including cyclic and linear forms. In the current work, the effect of six isolated Ncps structural variants 
on the activity of the human 205 proteasome was examined. The results indicate the differences in the activity of the cyclic and linear Ncp variants and show their selectivity in interaction with the proteasome active sites. Two of the linear peptides, Ncp-A2-L and Ncp-E2-L, inhibited the CT-L activity of the enzymatic complex without any effect on T-L and C-L sites. On the other hand, the cyclic Ncp-A2 had an inhibitory effect on T-L activity. The study also confirmed the importance of an aldehyde group for the interaction with the active center responsible for the CT-L activity. This is the first report on the inhibitory effect of Ncps on the 20S proteasome, which is an important drug target in various diseases.

Supplementary Materials: The following are available online at https:/ / www.mdpi.com/article/10 $.3390 /$ biom11101483/s1. Figure S1: ${ }^{1} \mathrm{H}$ NMR spectrum of Ncp-A2-L in $\mathrm{H}_{2} \mathrm{O}: \mathrm{D}_{2} \mathrm{O}$ (9:1), Figure S2: COSY spectrum of Ncp-A2-L in $\mathrm{H}_{2} \mathrm{O}: \mathrm{D}_{2} \mathrm{O}$ (9:1), Figure S3: TOCSY spectrum of Ncp-A2-L in $\mathrm{H}_{2} \mathrm{O}: \mathrm{D}_{2} \mathrm{O}$ (9:1), Figure S4: HSQC spectrum of Ncp-A2-L in $\mathrm{H}_{2} \mathrm{O}: \mathrm{D}_{2} \mathrm{O}$ (9:1), Figure S5: HMBC spectrum of Ncp-A2-L in $\mathrm{H}_{2} \mathrm{O}: \mathrm{D}_{2} \mathrm{O}(9: 1)$.

Author Contributions: Conceptualization: A.F. and H.M.-M.; methodology: H.M.-M., C.E. and F.K.; formal analysis: A.F., H.M.-M. (LC-MS/MS); A.F., M.C., F.K. and C.E. (extraction, fractionation, isolation of compounds); K.C. and A.F. (20S inhibition assay); writing original draft preparation: A.F.; writing review and editing: A.F., H.M.-M., E.W., C.E., K.C., M.C. and F.K.; visualization: A.F. and E.W.; supervision: H.M.-M.; project administration: H.M.-M.; funding acquisition: H.M.-M. All authors have read and agreed to the published version of the manuscript.

Funding: This research was funded by the National Science Centre in Poland 2016/21/B/NZ9/02304 and the statutory program of the Institute of Oceanology, PAN (grant No.II.3).

Institutional Review Board Statement: Not applicable.

Informed Consent Statement: Not applicable.

Data Availability Statement: Not applicable.

Conflicts of Interest: The authors declare no conflict of interest.

\section{References}

1. Kisselev, A.F.; Callard, A.; Goldberg, A. Importance of the different proteolytic sites of the proteasome and the efficacy of inhibitors varies with the protein substrate. J. Biol. Chem. 2006, 281, 8582-8590. [CrossRef]

2. Adams, J. The proteasome: Structure, function, and role in the cell. Cancer Treat. Rev. 2003, 29, 3-9. [CrossRef]

3. Deshmukh, F.K.; Yaffe, D.; Olsshina, M.A.; Ben-Nissan, G.; Sharon, M. The contribution of the 20S proteasome to proteostasis. Biomolecules 2019, 9, 190. [CrossRef]

4. Sherman, D.J.; Li, J. Proteasome inhibitors: Harnessing proteostasis to combat disease. Molecules 2020, 25, 671. [CrossRef] [PubMed]

5. Ciechanover, A.; Brundin, P. The ubiquitin proteasome system in neurodegenerative diseases: Sometimes the chicken, sometimes the egg. Neuron 2003, 40,427-446. [CrossRef]

6. Ciechanover, A. Proteolysis: From the lysosome to ubiquitin and the proteasome. Nat. Rev. 2005, 6, 79-86. [CrossRef]

7. Bedford, L.; Paine, S.; Sheppard, P.W.; Mayer, R.J.; Roelofs, J. Assembly, structure and function of the 26S proteasome. Trends Cell Biol. 2010, 20, 391-401. [CrossRef] [PubMed]

8. Orlowski, M.; Wilk, S. Ubiquitin-independent proteolytic functions of the proteasome. Arch. Biochem. Biophys. 2003, 415, 1-5. [CrossRef]

9. Hwang, J.; Winkler, L.; Kalejta, R.F. Ubiquitin-independent proteasomal degradation during oncogenic viral infections. Biochim. Biophys. Acta 2011, 1816, 147-157. [CrossRef]

10. Tundo, G.R.; Sbardella, D.; Santoro, A.M.; Coletta, A.; Oddone, F.; Grasso, G.; Milardi, D.; Lacal, P.M.; Marini, S.; Purrello, L.; et al. The proteasome as a druggable target with multiple therapeutic potentialities: Cutting and non-cutting edges. Pharmacor. Ther. 2020, 213, 107579. [CrossRef] [PubMed]

11. Verbrugge, S.E.; Scheper, R.J.; Lems, W.F.; de Gruijl, T.D.; Jansen, G. Proteasome inhibitors as experimental therapeutics of autoimmune diseases. Arthritis Res. Ther. 2015, 17, 17. [CrossRef]

12. Cao, Y.; Zhu, H.; He, R.; Kong, L.; Shao, J.; Zhuang, R.; Xi, J.; Zhang, J. Proteasome, a promising therapeutic target for multiple diseases beyond cancer. Drug Des. Devel. Ther. 2020, 14, 4327-4342. [CrossRef]

13. de Bettignies, G.; Coux, O. Proteasome inhibitors: Dozens of molecules and still counting. Biochimie 2010, 92, 1530-1545. [CrossRef]

14. Ma, Y.; Xu, B.; Fang, Y.; Yang, Z.; Cui, J.; Zhang, L.; Zhang, L. Synthesis and SAR study of novel peptide aldehydes as inhibitors of $20 \mathrm{~S}$ proteasome. Molecules 2011, 16, 7551-7564. [CrossRef] 
15. Harer, S.L.; Bhatia, M.S.; Bhatia, N.M. Proteasome inhibitors mechanism; source for design of newer therapeutic agents. J. Antibiot. 2012, 65, 279-288. [CrossRef]

16. Oerlemans, R.; Berkers, C.; Assaraf, Y.G.; Scheffer, G.L.; Peters, G.J.; Verbrugge, S.E.; Cloos, J.; Slootstra, J.; Meloen, R.H.; Shoemaker, R.H.; et al. Proteasome inhibition and mechanism of resistance to a synthetic, library-based hexapeptide. Investig. New Drugs 2018, 36, 797-809. [CrossRef]

17. Momose, I.; Sekizawa, R.; Hashizume, H.; Kinoshita, N.; Homma, Y.; Hamada, M.; Iinuma, H.; Takeuchi, T. Tyropeptins A and B, new proteasome inhibitors produced by Kitasatospora sp. MK993-dF2. J. Antibiot. 2001, 54, 997-1003. [CrossRef]

18. Momose, I.; Sekizawa, R.; Iinuma, H.; Takeuchi, T. Inhibition of proteasome activity by tyropeptin A in PC12 cells. Biosci. Biotechnol. Biochem. 2002, 66, 2256-2258. [CrossRef]

19. Hines, J.; Groll, M.; Fahnestock, M.; Crews, C.M. Proteasome inhibition by fellutamide B induces nerve growth factor synthesis. Chem. Biol. 2008, 15, 501-512. [CrossRef]

20. Golakoti, T.; Yoshida, W.; Chaganty, S.; Moore, R. Isolation and structure determination of nostocyclopeptides A1 and A2 from the terrestrial cyanobacterium Nostoc sp. ATCC53789. J. Nat. Prod. 2001, 64, 54-59. [CrossRef]

21. Lee, W.; Belkhiri, A.; Lockhart, A.C.; Merchant, N.; Glaeser, H.; Harris, E.I.; Washington, M.K.; Brunt, E.M.; Zaika, A.; Kim, R.B.; et al. Overexpression of OATP1B3 confers apoptotic resistance in colon cancer. Cancer Res. 2008, 68, 10315-10323. [CrossRef]

22. Svoboda, M.; Wleck, K.; Taferner, B.; Hering, S.; Stieger, B.; Tong, D.; Zeillinger, R.; Thalhammer, T.; Jäger, W. Expression of organic anion-transporting polypeptides 1B1 and 1B3 in ovarian cancer cells: Relevance for paclitaxel transport. Biomed. Pharmacother. 2011, 65, 417-426. [CrossRef]

23. Jokela, J.; Herfindal, L.; Wahlsten, M.; Permi, P.; Selheim, F.; Vasconçelos, V.; Døskeland, S.; Sivonen, K. A novel cyanobacterial nostocyklopeptide is a potent antitoxin against Microcystis. ChemBioChem 2010, 11, 1594-1599. [CrossRef]

24. Herfindal, L.; Myhren, L.; Kleppe, R.; Krakstad, C.; Selheim, F.; Jokela, J.; Sivonen, K.; Døskeland, S. Nostocyclopeptide-M1: A potent, nontoxic inhibitor of the hepatocyte drug trasporters OATP1B3 and OATP1B1. Mol. Pharm. 2011, 8, 360-367. [CrossRef]

25. Kotai, J. Introduction for Preparation of Modified Nutrient Solution Z8 for Algae; Norwegian Institute for Water Research Publication: Oslo, Norway, 1972.

26. Mazur-Marzec, H.; Fidor, A.; Cegłowska, M.; Wieczerzak, E.; Kropidłowska, M.; Goua, M.; Macaskill, J.; Edwards, C. Cyanopeptolins with trypsin and chymotrypsin inhibitory activity from the cyanobacterium Nostoc edaphicum CCNP1411. Mar. Drugs 2018, 16, 220. [CrossRef]

27. Czerwonka, A.; Fiołka, M.J.; Jędrzejewska, K.; Jankowska, E.; Zając, A.; Rzeski, W. Pro-apoptotic action of protein-carbohydrate fraction isolated from coelomic fluid of the earthworm Dendrobaena veneta against human colon adenocarcinoma cells. Biomed. Pharmacother. 2020, 126, 110035. [CrossRef]

28. Gaczyńska, M.; Osmulski, P.A.; Gao, Y.; Post, M.J.; Simons, M. Proline- and arginine-rich peptides constitute a novel class of allosteric inhibitors of proteasome activity. Biochemistry 2003, 42, 8663-8670. [CrossRef]

29. Nowruzi, B.; Khavari-Nejad, R.; Sivonen, K.; Kazemi, B.; Najafi, F.; Nejadsattari, T. Identification and toxigenic potential of Nostoc sp. Algae 2012, 27, 303-313. [CrossRef]

30. Liamer, A.; Jensen, J.; Dittman, E. A genetic and chemical perspective on symbiotic recruitment of cyanobacteria of the genus Nostoc into the host plant Blasia pusilla L. Front. Microbiol. 2016, 7, 1963. [CrossRef]

31. Fidor, A.; Grabski, M.; Gawor, J.; Gromadka, R.; Węgrzyn, G.; Mazur-Marzec, H. Nostoc edaphicum CCNP1411 from the Baltic Sea-a new producer of nostocyclopeptides. Mar. Drugs 2020, 18, 442. [CrossRef]

32. Guo, N.; Zhilan, P. MG 132, a proteasome inhibitor, induces apoptosis in tumor cells. Asia Pac. J. Clin. Oncol. 2013, 9, 6-11. [CrossRef]

33. Zhang, L.; Hu, J.J.; Gong, F. MG 132 inhibition of proteasome blocks apoptosis induced by severe DNA damage. Cell Cycle 2011, 10, 3515-3518. [CrossRef]

34. Hasegawa, M.; Kinoshita, K.; Nishimura, C.; Matsumura, U.; Shionyu, M.; Ikeda, S.; Mizukami, T. Affinity labeling of the proteasome by a belactosin A derived inhibitor. Bioorg. Med. Chem. Lett. 2008, 18, 5668-5671. [CrossRef]

35. Kisselev, A.F.; van der Linden, W.A.; Overkleeft, H.S. Proteasome inhibitors: An expanding army attacking a unique target. Chem. Biol. 2012, 19, 99-115. [CrossRef]

36. Kisselev, A.F.; Goldberg, A. Proteasome inhibitors: From research tools to drug candidates. Chem. Biol. 2001, 8, 739-758. [CrossRef]

37. Pereira, A.R.; Kale, A.J.; Fenley, A.T.; Byrum, T.; Debonsi, H.M.; Gilson, M.K.; Valeriote, F.A.; Moore, B.S.; Gerwick, W.H. The carmaphycins: New proteasome inhibitors exhibiting an $\alpha, \beta$-epoxyketone warhead from a marine cyanobacterium. ChemBioChem 2012, 13, 810-817. [CrossRef]

38. Shim, S.H.; Chlipala, G.; Orjala, J. Isolation and structure determination of a proteasome inhibitory metabolite from a culture of Scytonema hofmanni. J. Microbiol. Biotechnol. 2008, 18, 1655-1658.

39. Krunic, A.; Vallat, A.; Mo, S.; Lantvit, D.D.; Swanson, S.M.; Orjala, J. Scytonemides A and B, cyclic peptides with 20 S proteasome inhibitory activity from the cultured cyanobacterium Scytonema hofmanii. J. Nat. Prod. 2010, 29, 1927-1932. [CrossRef]

40. Chlipala, G.E.; Sturdy, M.; Krunic, A.; Lantvit, D.D.; Shen, Q.; Porter, K.; Swanson, S.M.; Orjala, J. Cylindrocyclophanes with proteasome inhibitory activity from the cyanobacterium Nostoc sp. J. Nat. Prod. 2010, 73, 1529-1537. [CrossRef]

41. Field-Smith, A.; Morgan, G.J.; Davies, F.E. Bortezomib (Velcade ${ }^{\mathrm{TM}}$ ) in the treatment of multiple myeloma. Ther. Clin. Risk Manag. 2006, 2, 271-279. [CrossRef] 
42. Herndon, T.M.; Deisseroth, A.; Kaminskas, E.; Kane, R.C.; Koti, K.M.; Rothmann, M.D.; Habtemariam, B.; Bullock, J.; Bray, J.D.; Hawes, J.; et al. Food and Drug Administration approval: Carfilzomib for the treatment of multiple myeloma. Clin. Cancer Res. 2013, 19, 4559-4563. [CrossRef]

43. Shirley, M. Ixazomib: First global approval. Drugs 2016, 76, 405-411. [CrossRef] [PubMed]

44. Bai, Y.; Su, X. Updates to the drug-resistant mechanism of proteasome inhibitors in multiple myeloma. Asia-Pac. J. Clin. Oncol. 2021, 17, 29-35. [CrossRef]

45. Kim, K.B. Proteasomal adaptations to FDA-approved proteasome inhibitors: A potential mechanism for drug resistance. Cancer Drug Resist. 2021, 4, 634-645.

46. Moreau, P.; Richardson, P.G.; Cavo, M.; Orlowski, R.Z.; Sam Miguel, J.F.; Palumbo, A.; Harousseau, J.-L. Proteasome inhibitors in multiple myeloma: 10 years later. Blood 2012, 120, 947-959. [CrossRef]

47. Pancheri, E.; Guglielmi, V.; Wilczynski, G.M.; Malatesta, M.; Tonin, P.; Tomelleri, G.; Nowis, D.; Vattemi, G. Non-hematologic toxicity of bortezomib in multiple myeloma: The neuromuscular and cardiovascular adverse effects. Cancers 2020, 12, 2540. [CrossRef]

48. Cromm, P.M.; Crews, C.M. The proteasome in modern drug discovery: Second life of highly valuable drug target. ACS Cent. Sci. 2017, 3, 830-838. [CrossRef] [PubMed]

49. Mofers, A.; Selvaraju, K.; Gubat, J.; D’Arcy, P.; Linder, S. Identification of proteasome inhibitors using analysis of gene. Eur. J. Pharmacol. 2020, 889, 173709. [CrossRef]

50. Shen, X.; Wu, C.; Lei, M.; Yan, Q.; Zhang, H.; Zhang, L.; Wang, X.; Yang, Y.; Li, J.; Zhu, Y.; et al. Anti-tumor activity of a novel proteasome inhibitor D395 against multiple myeloma and its lower cardiotoxicity compared with carfilzomib. Cell Death Dis. 2021, 12, 429. [CrossRef] 